\section{Vil radiologer bli erstattet av kunstig intelligens?}

KRONIKK

\section{ANDREAS ABILDGAARD}

E-post: aabildga@ous-hf.no Andreas Abildgaard er seksjonsleder i Seksjon for abdominalradiologi, Avdeling for radiologi, Rikshospitalet, Klinikk for radiologi og nukleærmedisin, Oslo universitetssykehus. Forfatter har fylt ut ICMJE-skjemaet og oppgir ingen interessekonflikter.

\section{EINAR HOPP}

Einar Hopp er avdelingsleder i Avdeling for radiologi, Rikshospitalet, Klinikk for radiologi og nukleærmedisin, Oslo universitetssykehus.

Forfatter har fylt ut ICMJE-skjemaet og oppgir ingen interessekonflikter.

\section{TOMAS SAKINIS}

Tomas Sakinis er radiolog ved Avdeling for radiologi, Rikshospitalet, Klinikk for radiologi og nukleærmedisin, Oslo universitetssykehus.

Forfatter har fylt ut ICMJE-skjemaet og oppgir ingen interessekonflikter.

\section{HÅVARD ROTERUD}

Håvard Roterud er radiograf og helsefaglig rådgiver i stab, Klinikk for radiologi og nukleærmedisin, Oslo universitetssykehus, og tilknyttet Seksjon for teknologisk drift.

Forfatter har fylt ut ICMJE-skjemaet og oppgir ingen interessekonflikter.

\section{ATLE BJØRNERUD}

Atle Bjørnerud er professor i biofysikk og medisinsk fysikk ved Avdeling for diagnostisk fysikk, Klinikk for radiologi og nukleærmedisin, Oslo universitetssykehus.

Forfatter har fylt ut ICMJE-skjemaet og oppgir ingen interessekonflikter.

\section{MONA BEYER}

Mona Beyer er seksjonsleder i Seksjon for nevroradiologi, Avdeling for radiologi, Rikshospitalet, Klinikk for radiologi og nukleærmedisin, Oslo universitetssykehus. Forfatter har fylt ut ICMJE-skjemaet og oppgir ingen interessekonflikter.

\section{HANS-JØRGEN SMITH}

Hans-Jørgen Smith er professor emeritus i radiologi ved Universitetet i Oslo, og tidligere leder av Klinikk for radiologi og nukleærmedisin, Oslo universitetssykehus.

Forfatter har fylt ut ICMJE-skjemaet og oppgir ingen interessekonflikter.

Kunstig intelligens kan brukes til bildeanalyse. Kan radiologene erstattes av lærevillige datasystemer uten lunsjpause? 


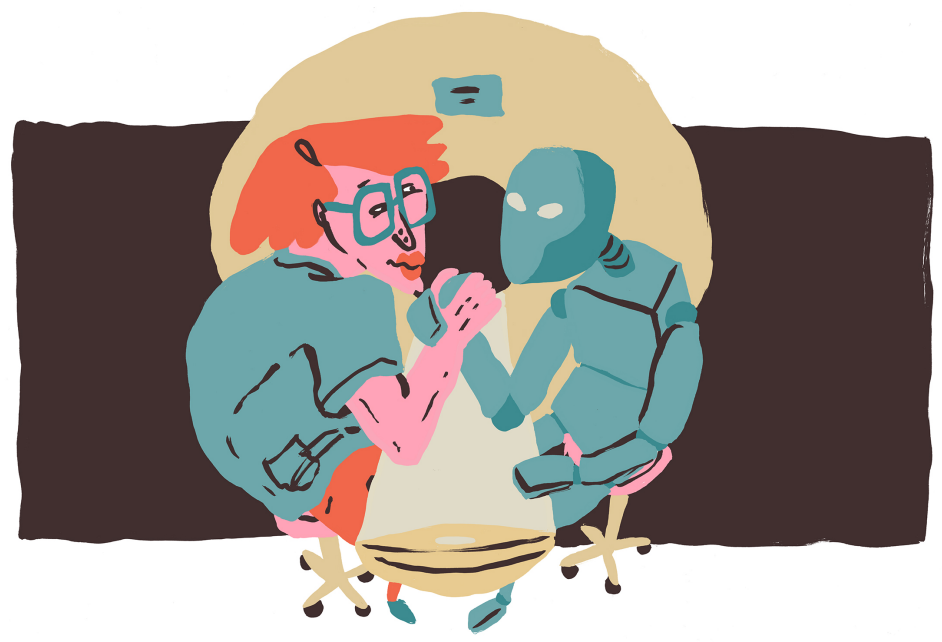

Illustrasjon: Helene Brox.

Hvert år deltar dataprogrammer i konkurransen «ImageNet Challenge», hvor dagligdagse objekter skal identifiseres i fargebilder og klassifiseres riktig blant 1 ooo kategorier (1). I 2015 var de beste systemene omtrent like dyktige som mennesker. Etter dette er vi forbigått. Maskinene er blant annet bedre enn oss til å identifisere 10o forskjellige hunderaser.

\section{Maskinlæring}

En datamaskin utfører instruksjoner som er spesifisert i programmer. Enkle programmer opererer etter fastlagte regler, og oppgavene løses likt hver gang. Mer avanserte programmer kan ha evne til læring; de justerer seg slik at oppgaver utføres bedre og bedre. Maskinlæring er et sentralt konsept innenfor begrepet kunstig intelligens (artifical intelligence, AI). Programmer for bildeanalyse med maskinlæring har ofte en oppbygging som kalles nevrale nettverk, en parallell til nevronnettverk i hjernen. De virtuelle nevronene mottar inngående signaler gjennom multiple kanaler, prosesserer signalene og avgir respons. De er organisert i flere lag, hvor informasjonen håndteres suksessivt. Maskinlæring i nevrale nettverk med mange lag kalles også «deep learning».

\section{Maskinlæring i radiologisk diagnostikk}

Nevrale nettverk kan oppdage forandringer i radiologiske bilder og foreslå diagnoser (2-6). De kan klassifisere generalisert organaffeksjon og gi anslag om prognose (7-9). De diagnostiske oppgavene i publiserte studier er ofte svært avgrensede og ganske fjerne fra den kliniske hverdagen, men tendensen er klar: Nettverkene presterer stadig bedre og kan brukes til mer komplekse oppgaver. Samtidig er det blitt klart at teknologien har begrensninger. For å synliggjøre dette vil vi omtale virkemåten for slike nettverk.

\section{Konvolusjonelle nevrale nettverk}

Konvolusjonelle nevrale nettverk er mye brukt for maskinbasert klassifikasjon av objekter i bilder. De første lagene i nettverket henter ut ulike aspekter av bildeinformasjon, og de etterfølgende lagene prosesserer informasjonen.

Et bilde som skal analyseres, håndteres som et stort rutenett (en matrise) av signalverdier angitt som tall. I de første lagene i nettverket gjøres mange konvolusjoner på denne bildematrisen. En konvolusjon betyr i denne sammenheng at et "filter» (en liten tallmatrise) forflyttes suksessivt gjennom bildematrisen mens det gjøres utregninger som uttrykker et samsvarsforhold mellom filteret og det aktuelle området i bildematrisen. Tallmatrisen i filteret svarer til en bestemt geometrisk form eller struktur. Konvolusjonen resulterer i en ny tallmatrise som avspeiler forekomsten av denne geometrien i bildet. Det gjøres konvolusjoner med mange forskjellige filtre. De nye tallmatrisene brukes i nye konvolusjoner, som igjen gir nye tallmatriser som avspeiler mer komplekse 
bildestrukturer. Slik bygges det opp et hierarki av karakteristika for det aktuelle bildet. Informasjonen prosesseres videre $\mathrm{i}$ «konvensjonelle» nevrale nettverksstrukturer, og det avgis et resultat med diagnoseforslag. Department of Computer Science ved Ryerson University, Canada, illustrerer et konvolusjonelt nettverk for identifikasjon av tallsiffer (10).

For å lære seg diagnostikk må nettverket trenes med et stort antall bilder hvor fasiten er gitt. Nettverket starter treningen med tilfeldig valgte filtre og med noen utgangsverdier for vektingen av signaloverføring mellom nevronstrukturene. Hvis diagnosen er feil, blir filtrene og vektingene justert. Så prøves det igjen og igjen. Når vektinger og filtre er optimalisert mot treningsbildene, testes nettverket mot nye bilder for å verifisere at klassifiseringen er robust.

Det er utfordrende å fremskaffe tilstrekkelig antall treningsbilder til nevrale nettverk for radiologisk diagnostikk. Alle diagnostiske alternativer som nettverket skal mestre, må være representert med mange eksempler i treningsbildene. Man har forsøkt å automatisere klassifikasjonen av bilder ved å kombinere dem med radiologiske svarrapporter, men det er fortsatt nødvendig at fagpersoner kvalitetssikrer klassifikasjonen (11). Bildebruken utfordrer også personvernet. I henhold til EUs personvernforordning skal personopplysninger behandles transparent, en person skal kunne vite hvordan opplysningene brukes. Det er ikke opplagt hvordan dette innfris i et nevralt nettverk. Det gis også begrensninger for bruk av personopplysninger til andre formål enn det de opprinnelig ble registrert for.

\section{Den svarte boksen}

En radiolog som vurderer en levertumor på CT-bilder, vil vurdere tumorstørrelse, form, avgrensning, vekstmønster, kontrastoppladningsmønster og så videre. Dette er kjente og kommuniserbare tumoregenskaper som kan vurderes ut fra faglig kunnskap. Nevrale nettverk i radiologi analyserer ikke forhåndsdefinerte egenskaper, de finner selv frem til et hierarki av bildeegenskaper som er relevante for klassifikasjon. Disse «egenskapene» er logiske og matematiske strukturer som håndteres i mange millioner regneoperasjoner. Derfor får vi ikke full oversikt over hvordan diagnostikken gjøres. Nettverket fungerer som en svart boks som mottar bildeinformasjon og leverer en diagnose, og vi vet ikke hvordan.

La oss si at et nevralt nettverk har brukt noen hundre cerebrale MR-undersøkelser for å lære seg å diagnostisere Alzheimers sykdom. Treffsikkerheten er god, og nettverket tas i bruk i diagnostikk. Så anskaffes en ny og annerledes MR-maskin. Da er det behov for ny testing av nettverket. Man kjenner ikke detaljene i hvordan nettverket vurderer bildene og kan derfor ikke forutsi hvordan det vil prestere med bilder som kan ha en litt annen tekstur eller være forskjellige på andre måter. Når nevrale nettverk slik vi nå kjenner dem, brukes i radiologisk diagnostikk, vil det være behov for ny testing og validering hver gang bildeproduksjonen endres. Dette gjelder selv om endringene er beskjedne, som for eksempel justering av ekkotiden i et T2-vektet MR-opptak.

Et annet aspekt gjelder kunnskapsutveksling. En erfaren radiolog kan forklare yngre kolleger hvilke premisser som legges til grunn for en diagnose. Et nevralt nettverk som fungerer som en svart boks, kan ikke forklare sin diagnostiske prosess. Et slikt nettverk bidrar derfor lite til å videreutvikle radiologenes diagnostiske resonnementer. Tilsvarende er det begrenset mulighet for radiologene til å gjøre nettverket bedre, bortsett fra å fôre det med ytterligere treningsbilder.

Den svarte boksen gir også medisinsk-juridiske utfordringer. Hvis en radiolog stiller feil diagnose, vil det som regel kunne avklares hvordan feilen oppsto. Feilen gir stor læringseffekt, som kan kommuniseres til kolleger. Hvis et nevralt nettverk stiller feil diagnose, vet man i utgangspunktet svært lite om mekanismen eller faren for gjentagelse. Det kan være uklart hvem som har ansvaret for feilen. Var programmeringen feil, var læringsprosessen mangelfull, eller er det andre årsaker? Skal selgeren eller sykehuset saksøkes? 


\section{$\AA$ A forklare sin analyse}

Som det fremgår, har vi behov for kunnskap om hvordan den svarte boksen gjør sine klassifikasjoner og diagnostiske vurderinger. Dette er blitt et viktig forskningsfelt. Man kan lage "varmekart» (heatmaps) som viser hvilke deler av et bilde som har vært mest vesentlig for klassifikasjonen. Det har vært forsket på teknikker for å få nettverket til å forklare sin analyse ut fra bildeegenskaper som mennesker kan relatere til. En fugleklassifikasjon kan forklares med «dette er en hakkespett, fordi den har hvitt bryst, sorte vinger og en rød flekk på hodet». For leverlesjoner har man forsøkt å etablere forbindelser mellom enkle, kvantiterbare bildeegenskaper og radiologenes lesjonsbeskrivelse (12). En annen tilnærming er å ta utgangspunkt i et ferdig trent nettverk som gjør klassifikasjoner av bildefunn, og la et annet nettverk forsøke å generere bildedata som passer til disse klassifikasjonene. De kunstige bildene kan indikere hvilke karakteristika som ligger til grunn for klassifikasjonen. Men foreløpig finnes det ikke løsninger som gir oss reell oversikt over nettverkenes analyse. Dette er en viktig begrensning for bruk av kunstig intelligens i selvstendig radiologisk diagnostikk.

\section{Andre bruksområder}

Kunstig intelligens vil kunne støtte mange arbeidsprosesser på radiologiske avdelinger. I flere av disse kan den brukes uten at svart boks-situasjonen blir problematisk. Dette er også viktig for leverandører av bildehåndteringssystemer, som ønsker minimal risiko for uønskede konsekvenser.

Kunstig intelligens kan lage effektive presentasjoner av store mengder radiologiske bildedata og kan ved forløpskontroller gjenfinne og presentere patologiske forandringer i pasientenes tidligere undersøkelser. Dette skjer gjennom automatiserte størrelsesmålinger og kvantitering av endringer.

I et radiologisk bildeopptak blir anatomi registrert som modalitetsspesifikke signalverdier, som deretter blir rekonstruert tilbake til anatomiske bilder. Det forskes på mange former for kunstig intelligens-støtte for å forbedre rekonstruksjonsteknikkene. En drastisk variant er å la den erstatte rekonstruksjonsteknikkene fullstendig; man trener et nevralt nettverk til å produsere bilder direkte ut fra opptakssignalene (13).

\section{Nye arbeidsmåter}

Kunstig intelligens vil overta en del bildehåndteringsoppgaver og bistå i mange delfunksjoner i den radiologiske arbeidsprosessen. Slike løsninger kan avlaste både radiologer og radiografer. Leverandører av informasjonssystemer for radiologi har begynt å ta inn disse løsningene i sine systemer. Etablering av kunstig intelligens i radiologisk rutinediagnostikk går langsommere. Det finnes løsninger for avgrensede diagnostiske oppgaver, for eksempel bestemmelse av skjelettmodning. Og det gjøres spennende radiologisk forskning på området, også i Norge. Men samlet sett er det mye som tyder på at kunstig intelligens i overskuelig fremtid hovedsakelig vil fungere som et kvalitetsforbedrende supplement til radiologenes diagnostikk, ikke som en erstatning. Radiologenes arbeid omfatter dessuten langt mer enn bildediagnostikk: intervensjon, kommunikasjon, dokumentasjon, undervisning, forskning, organisering og så videre.

Håndtering av radiologiske signaldata og bilder i nevrale nettverk gir nye oppgaver for fysikere og IT-personell. Vi forventer nye former for tverrfaglig samarbeid, med tettere kobling mellom teknologiutvikling og klinisk diagnostikk.

\section{Nøktern begeistring}

Vi lever i en tid med endringsentusiasme, med varsler om undergang dersom man ikke kaster seg rundt og tar i bruk nye digitale muligheter. Vi må balansere entusiasmen med nøktern realisme og ta teknologien i bruk på best mulig måte for våre pasienter. Kunstig 
intelligens er til dels en «hype», men samtidig en kraftfull teknologi som vil endre vår hverdag vesentlig. Medisinsk bruk må baseres på vitenskapelig dokumentasjon.

Implementering av radiologisk kunstig intelligens krever innsats fra mange yrkesgrupper, ikke minst radiologer. I Norge er det radiologmangel. Ut fra hva vi vet nå, vil dette vedvare i lang tid.

\section{LITTERATUR:}

1. Russakovsky O, Deng J, Su H et al. ImageNet Large Scale Visual Recognition Challenge. Int J Comput Vis 2015; 115: 211 - 52. [CrossRef]

2. Yang Y, Feng X, Chi W et al. Deep learning aided decision support for pulmonary nodules diagnosing: a review. J Thorac Dis 2018; 10 (suppl 7): S867 - 75. [PubMed][CrossRef]

3. Yasaka K, Akai H, Abe O et al. Deep learning with convolutional neural network for differentiation of liver masses at dynamic contrast-enhanced CT: A preliminary study. Radiology 2018; 286: 887 - 96. [PubMed][CrossRef]

4. Zaharchuk G, Gong E, Wintermark M et al. Deep learning in neuroradiology. AJNR Am J Neuroradiol 2018. [PubMed][CrossRef]

5. Olczak J, Fahlberg N, Maki A et al. Artificial intelligence for analyzing orthopedic trauma radiographs. Acta Orthop 2017; 88: 581 - 6. [PubMed][CrossRef]

6. Chartrand G, Cheng PM, Vorontsov E et al. Deep learning: A primer for radiologists. Radiographics 2017; 37: 2113-31. [PubMed][CrossRef]

7. Anthimopoulos M, Christodoulidis S, Ebner L et al. Lung pattern classification for interstitial lung diseases using a deep convolutional neural network. IEEE Trans Med Imaging 2016; 35:1207-16. [PubMed][CrossRef]

8. Yasaka K, Akai H, Kunimatsu A et al. Deep learning for staging liver fibrosis on CT: a pilot study. Eur Radiol 2018. [PubMed][CrossRef]

9. Nielsen A, Hansen MB, Tietze A et al. Prediction of tissue outcome and assessment of treatment effect in acute ischemic stroke using deep learning. Stroke 2018; 49: 1394 - 401. [PubMed][CrossRef]

10. 2D visualization of a convolutional neural network. Department of Computer Science, Ryerson University. http://scs.ryerson.ca/ aharley/vis/conv/flat.html (10.9.2018).

11. Shin H-C, Lu L, Kim L et al. Interleaved text/image deep mining on a large-scale radiology database for automated image interpretation. JMLR 2016; 17: 1 - 31.

12. Banerjee I, Beaulieu CF, Rubin DL. Computerized prediction of radiological observations based on quantitative feature analysis: initial experience in liver lesions. J Digit Imaging 2017;30: 506 - 18. [PubMed][CrossRef]

13. Zhu B, Liu JZ, Cauley SF et al. Image reconstruction by domain-transform manifold learning. Nature 2018; 555: 487-92. [PubMed][CrossRef]

Publisert: 19. oktober 2018. Tidsskr Nor Legeforen. DOI: 10.4045/tidsskr.18.0587

Mottatt 20.7.2018, første revisjon innsendt 10.9.2018, godkjent 3.10.2018.

(C) Tidsskrift for Den norske legeforening 2020. Lastet ned fra tidsskriftet.no 